\title{
Mothering in the Context of Poverty: Disciplining Peruvian Mothers through Children's Rights
}

\author{
Dena Aufseeser ${ }^{1 *}$
}

Published: September 10, 2019

\begin{abstract}
This article explores discourses surrounding poverty and mothering in the context of Peru. It specifically suggests that claims in the name of children's rights provide a more morally acceptable way to discipline economically disadvantaged mothers. Mothers are framed as 'bad parents' when their children fail to experience so-called 'global childhoods', spent in school and the home, and not in paid work. However, in Andean culture, children begin working alongside their parents at a young age as they learn to become active members in society. Rather than recognising motherhood as socially constructed, internationally-funded NGOs and government officials emphasise a need to teach mothers about the cultural dangers of work. However, I suggest that in doing so, poverty is reframed as a cultural problem, of which mothers are to blame. This overlooks significant economic inequality as well as different conceptions of motherhood and childhood. The article examines how mothers negotiate competing demands in the context of discourses of global childhood, and is based on field work conducted over 14 months in 2009 and 2010, with follow up research in 2011 and 2014.
\end{abstract}

Keywords: motherhood, children's rights, intersubjectivity, critical poverty studies

\section{INTRODUCTION}

This article explores discourses surrounding poverty and mothering in the context of Peru. Debates that put children's rights into tension with women's rights are not new within feminist literature. Children's rights have even been framed as a constraint on women's rights, and vice-versa (Burman, 2008; Ruddick, 2007). Children themselves are also portrayed as a burden or a limitation to women's opportunities. However, less research specifically examines the ways in which the idea of global childhood, framed as time to be in school and in play, rather than working, depoliticises efforts to discipline the poor mother. I argue that claims in the name of children's rights rely on problematic assumptions about what childhood should look instead of considering children's actual well-being or the tradeoffs that children (and their parents) make in the context of their daily lives. Instead, mothers are framed as 'bad parents' if children's lives do not mirror those depicted in discourses of global childhood.

As the most widely ratified UN Convention in the world, the Convention on the Rights of the Child represents a formal commitment from governments, child advocates, international organisations and others to actively strive to ensure children's rights. As such, it offers a framework for shared responsibility for children's well-being that extends beyond mothers (or even the family). However, children's rights regimes are critiqued for presenting middle-class Western experiences of childhood as universal (Invernizzi and Williams, 2008; Liebel, 2006). Different experiences, such as working or spending time in public spaces, are viewed as problematic indicators of children's well-being. It is beyond the scope of this article to rehearse all the debates about children's work (see Aufseeser et al., 2018; Bourdillon, 2006). Instead, I examine the ways in which mothers are blamed when their children fail to experience supposedly 'global' childhoods.

Drawing on over 14 months of field work in Lima and Cusco, Peru, I focus on how mothers of working children negotiate various practices of mothering in the context of poverty. Media articles, social services, and internationally-funded NGOs draw attention to the dangers of child labour and specifically vilify mothers who 'allow' children to work. However, in Andean culture, children begin working alongside their parents at a young age. In such situations, work is an important space in which young people learn to become active members in society (Bolin, 2006; Cussianovich, 2006). Child circulation, or the practice of sending children to live with 
wealthier connections or relatives, may also be part of mothers' strategies to help their children 'get ahead' (Leinaweaver, 2006). Among childhood studies scholars, it is now well-recognised that childhood is a socially constructed experience (Aitken, Lund, and Kjorholt, 2008). However, much less work extends this recognition to constructions of motherhood. This article argues that poor mothers are framed in problematic ways that overlook different conceptions of motherhood and childhood, as well as significant economic inequality and histories of exploitation. Over the course of my research, explanations for child poverty centred on mothers, especially indigenous mothers, depicting them as irresponsible, having too many children, and to blame for their children's poverty. However, these tropes are limited for two main reasons. First, by relabelling poverty as 'cultural', the structural conditions that contribute to poverty and exploitative work are overlooked. Second, because of the veneer of moral respectability that accompanies programs carried out in the name of children's rights (see Pupavac, 2002), actual understandings of what accounts for good mothering are not subject to much critique. In this way, children's rights regimes provide a new rationality through which to govern poor women.

\section{'Women and Children' or 'Women versus Children'}

Enloe (1990) argues that women and children are tied together to such an extent that they become the singular 'womenandchildren', which is reflective of women's greater role in caring for children, and a tendency to lump women and children's vulnerabilities together (Burman, 2008). Feminist scholars and activists critiqued this tendency for overlooking women's needs and subsuming them under children's needs. In contrast, they argue for the need to view women and children in distinctive categories (Monk and Hanson, 1982). Efforts to unlink the two, however, have ironically reinforced potential conflict between children's rights and women's rights. Portraying something as a conflict between women's rights and children's rights may divert attention from larger issues (Burman, 2008) -in this case the ways in which economic inequality and long-term societal exclusion actively perpetuate children's disadvantage. Additionally, as I elaborate below, these efforts overlook the interdependency of subjects.

\section{Governing Poor Mothers}

Social services have long been associated with the creation of particular subjects (Kingfisher and Maskovsky, 2008). In the context of addressing children's poverty, portrayals of children as dependent and vulnerable frequently intertwine with frameworks that depict mothers as ultimately responsible for their children (Rosen and Twamley, 2018; Cassiman, 2008). This link starts early. Imagery around pregnant women's bodies hold mothers accountable for the child's well-being, thus overlooking larger structural concerns (Ruddick, 2007). In the context of the United States, studies suggest that poor black women are particularly vulnerable to discipline in the name of their children's well-being (Roberts, 1991). Poor women must give up their own rights in order to secure benefits for their children (Cassiman, 2008). There are parallels between discourses about black 'welfare queens' and portrayals of 'dirty' indigenous mothers. In Latin America, research demonstrates how notions of 'bad mothers' overlook ongoing inequalities and exploitation (Leinaweaver, 2006; Swanson, 2007; Campoamor, 2016).

By adding the element of rights discourse as a rationality used to govern and discipline poor mothers, I expand literature that critically assesses the relationship between charity and morality. I employ Foucault's (1991) ideas of governmentality to draw attention to the ways in which ideas of 'global childhood' translate into notions of 'global motherhood,' operating and spread through what Pupavac (2002) refers to as international children's rights regimes. Such an approach allows space for consideration of the ways in which circulating discourses of global childhoods provide a tool for governmental agencies and NGOs to discipline mothers at the same time as such rationalities shape particular subjectivities about 'good' mothering. Conceptions of global motherhood overlook how ideas of motherhood, like childhood, are socially constructed and need to be contextualised. For example, in the Andean highlands, parents try to raise respectful hard-working children who learn through observation (Bolin, 2006). To do so, children accompany their parents and other community members throughout the day, rather than occupy separate spaces. However, since the ratification of the UN Convention on the Rights of the Child in 1990, NGOs working with impoverished parents increasingly employ a language of children's entitlements, positioning parents as responsible for failing to fulfil these entitlements (Nieuwenhuys, 2001). They impose Western views of what constitutes 'normal' childhoods on children of the poor. Internationally-funded NGOs emphasise a need to teach mothers about the dangers of work. If mothers, or organisations that support mothers, speak out against these efforts, they risk being vilified for not caring about their children.

\section{The Peruvian Context}

In the last 15 years, Peru has experienced rapid economic growth and poverty reduction. However, inequality remains high, with a long history of exploiting and devaluing indigenous populations (Thorp and Paredes, 2010). According to UNICEF, as of 2009, 78 percent of children whose first language was Quechua or Aymara lived in poverty, compared to 40 percent of those who spoke Spanish as their first language. Colonisers not only 
dispossessed and exploited indigenous populations, they also established firm hierarchies about worth and value. White and mestizo populations were linked with modernity and development, in contrast to indigenous populations, who were framed as backwards (Thorp and Paredes, 2010). Even today, Peru's indigenous populations are associated with the highlands region (as well as the jungle region), and are presented as 'out of place' in urban spaces (Seligmann, 2012).

In the late 1980s and early 1990s, as a result of violence from conflict with Shining Path, an insurgent terrorist group, many Quechua-speakers migrated from Peru's highland region to Lima. Shining Path's violence and coercion, and eventual use of terror, devastated rural populations. The hardship they faced doubled as the military retaliated with their own violence. Discourses of the indigenous population's inherent inferiority provided the justification for more extreme forms of violence, and one leader admitted to using the indigenous population as 'cannon fodder' (Thorp and Paredes, 2010). By the end of the conflict, nearly 70,000 had died, 85 percent of whom were native-Quechua speakers. The violence heightened migration trends that were already well under-way in response to historical and regional inequalities. An estimated 600,000 to 1,000,000 fled their home town, and institutions, families, and livelihoods were destroyed. The influx of migrants into Lima only added to growing feelings of insecurity and fear, reinforced by beliefs that indigenous populations belonged in rural areas. Today, 9.1 percent of Lima's population speaks Quechua as their native tongue (DIDP, 2018) ${ }^{1}$ and 39.1 percent migrated to Lima from other parts of the country. ${ }^{2}$ However, policies still reflect a denigration of indigenous culture and suspicion around indigenous presence in public spaces.

During Peru's conflict with Shining Path, the country also faced an economic crisis, leading to decreased funding for social services and skyrocketing poverty and inequality rates (Leon, 2013). Then-president Alberto Fujimori implemented a series of structural adjustment changes in which markets were opened to foreign competition and tariffs were removed or drastically reduced. Real wages fell, with people reporting longer working hours just to make ends meet (Yamada, 2005). This had direct consequences on parents' ability to both earn money for the family and directly supervise their children. At the same time, already limited budgets for social services were slashed. Rather than emphasising education, health, and infrastructure as public goods, social policy shifted to target specific groups of poor people (Leon, 2013). Women (and children) stepped in to compensate for the withdrawal of the state (Hays-Mitchell, 2002).

In 1990, the same year that Alberto Fujimori became president, Peru formally embraced children's rights, ratifying the UN Convention on the Rights of the Child. In doing so, the government guaranteed all children the right to accessible education, health, and an adequate standard of living, among others. International children's rights organisations, and the funding that accompanied their campaigns, offered the potential to counter neoliberal policies' emphasis on individual responsibility for social reproduction. According to UNICEF, the state, institutions, community, family and individuals all share responsibility to protect and promote the rights of children.

However, in practice, both NGOs and state-run programs continued to emphasise mothers' responsibilities for their children's well-being, with the state and NGOs playing advisory roles. Social services frequently require behavioural changes or increased responsibilities from mothers to access benefits for children. Even V aso de Leche, or Glass of Milk, which is one of Peru's oldest social programs, depends on mothers preparing food in their homes and then delivering food to daycares and schools (Leon, 2013). Further, the state only provides limited child care, focusing on children under the age of 3 , with few available spots and limited hours.

In some situations, mothers did actively take the lead to address crises in their children's well-being, setting up public dining halls that provided affordable food and a space for women to organise. However, as public kitchens evolved and received more state and international funding, they also became a space in which the state could govern economically disadvantaged women (Schroeder, 2006). For example, social workers would require mothers to attend educational seminars, in which they were 'taught' about 'proper' hygiene and nutrition. Educational materials often implied that indigenous women were not concerned with cleanliness (Schroeder, 2006). Limited access to water and nutrients then became secondary to culture and a lack of proper education.

In 2005, following purported successes with cash transfer programs in Mexico and Brazil, the Peruvian government created its own cash transfer program, Juntos. As is the case with other conditional cash transfer programs, Juntos was premised on the idea that mothers were more likely to invest in their families and communities than were men, and therefore should be the official recipients of cash transfers. However, the transfers came with specific obligations. To receive financial assistance, mothers must send their children to school and to health clinics (Leon, 2013; Molyneux, 2006). If mothers miss appointments, they risk being viewed as 'bad mothers' who do not care for their children (Bradshaw and Viquez, 2008), with little discussion of factors such as the availability and quality of schooling or clinics. Further, program success is measured based on improved outcomes for children

\footnotetext{
${ }^{1}$ In contrast, in the region of Cusco, nearly 75 percent of the population self-identifies as Quechuan (DIDP, 2018).

2 While migrants often have closer links to indigenous communities, it is important to note that these numbers represent total migration, rather than migration of the indigenous population, of which specific numbers are not available.
} 
specifically. The guide for Juntos makes this distinction clear, stating that the intended beneficiaries of the program are children, and that mothers hold the responsibility of fulfilling certain duties to ensure their children's access to benefits. Further, the whole program is based on the inherent assumption that poor mothers are unable to properly invest in their children without 'guidance' from the state or international donors. Although not all families that participate are indigenous, the program initially targeted rural communities most affected by political violence of the 1980s, which led to a disproportionate number of indigenous participants. It is in this context that I analyse social services and discourses targeting working children and their families.

\section{Methods}

This project arose from a research project that examined the everyday lives of Peruvian children who worked or lived in public spaces. Over the course of 14 months of research in 2009 and 2010 in Lima and Cusco, Peru, it became apparent that children's well-being and mother's well-being were linked. Shadowing programme staff at NGOs, accompanying children while they played, worked, or hung out in the streets, and formally interviewing 69 children and over 100 social workers, educators, government officials, NGO staff, and police about the causes of children's poverty revealed a strong emphasis on maternal responsibility and morality, or a lack thereof. ${ }^{3} \mathrm{I}$ also formally interviewed four mothers whose daughters sold artisan goods and snacks in Cusco's main plaza. To elaborate on informal conversations, interviews and participant observation with children and their mothers, and learn more about how mothers themselves negotiated competing identities and obligations, I conducted an additional eight semi-structured interviews with mothers in 2011 and $2014 .{ }^{4} \mathrm{I}$ had met all the mothers on whom I focused over the course of earlier fieldwork, and all had children who worked in public spaces. Five had migrated from smaller communities in the Andean highlands and one had migrated from Peru's jungle region, and were of indigenous descent. Two women had grown up in informal communities on Lima's desert hills, and were children of migrants from the Andean highlands. I also interviewed an 18-year old woman who had participated in the study as a child, and had gone on to herself have children over the course of my fieldwork, as well as a 25 -year old, who had slept on the streets from the time she was 8 until she became pregnant with her son. In addition, I engaged in critical discourse analysis of Peru's National Plan for Children and Adolescents, Peru's National Strategy for the Prevention and Eradication of Child Labour, 2002-2021, Juntos' cash transfer program manuals, and reports and programme statements from Peru's Institute for Family Well-Being (INABIF), as well as other relevant social policy plans and media accounts. Policies, laws, and media play an important role in particular forms of subjectification, shaping 'truths' about childhood, motherhood, deservability and responsibility (see Foucault, 1991). I analysed texts to look for similarities, differences and patterns in the ways in which statements and goals reflected certain assumptions about childhood, responsibility and poverty, based on the premise that language is used to affect certain agendas (see van Dijk, 2001).

Critiques of charities' role in disciplining poor mothers and holding them responsible for their children's poverty are not new. However, I argue that a language of children's rights depoliticises the blame and responsibility put on mothers. Because 'rights' are framed as progressive and empowering, they are not subject to as much scrutiny as are more directly punitive policies. Furthermore, discourses of mothering are powerful because they operate in ways that disadvantaged mothers themselves not only resist but also internalise. Through their actions, mothers challenge representations that frame them as uncaring and exploitative while simultaneously reaffirming other components of ideal mothering, such as notions of sacrifice. In the sections that follow, I show that while children's rights discourses offer the potential for shared responsibility for child well-being, in their implementation, poor mothers continue to be held primarily responsible for children's well-being. I then analyse ways in which anti-child labour programs provide a venue through which to discipline mothers. Finally, I discuss the contradictory ways in which mothers both reproduce and challenge representations of 'good mothers'.

\section{Children's Rights: Shared or Individual Responsibility?}

Through social policy and discourse, the Peruvian government sends mixed messages about who holds responsibility to ensure children's rights. While Peru's National Plan for Children and Adolescents emphasises coresponsibility of the state, civil society, and the family to safeguard children's rights, it also highlights the special role and responsibility of the mother. For example, it discusses a need to "orient the family, through the mother, to apply healthy habits of hygiene" (PNAIA, 2012, 41). ${ }^{5}$ Further, it describes the family as "the fundamental nucleus of society, and the most adequate space for growth". Yet, it goes on to say that although the family has the potential to be a fundamental nucleus, it is also a space in which many girls' and boys' integrity and rights are violated. These competing statements reflect the tensions within society of both honouring the place of the family

\footnotetext{
${ }^{3}$ Interviews were semi-structured, and ranged from 15 minutes to 90 minutes. Field notes from participant observation and informal conversations with mothers provided further data.

${ }^{4}$ Names of mothers and children interviewed have been changed.

5 All translations are mine.
} 
and fearing it as a place of exploitation. In situations in which the state discusses co-responsibility, it is ultimately about a shared responsibility to implement one specific type of childhood, in this case, childhood spent in school and the home, and not working, especially outside of the house. Motherhood then becomes about creating this type of childhood, rather than entertaining multiple ways of mothering.

Peru's National Plan highlights children's labour as a risk factor, drawing special attention to labour that is carried out in the street and other public spaces. Although the Plan acknowledges that "poverty is the main cause" of children's work, it also formally highlights the role of culture and the positive valuation of work as key problems (PNAIA, 2012, 70). The National Plan to Protect and Eradicate Children's Labour similarly links children's work with culture. It explains that in some parts of Peru, traits of 'a good child' include the attribute of being hardworking. However, it goes on to say that parents' capacity to reflect on motives, consequences and alternatives to child labour is important. According to the plan, when this capacity is lacking, parents need to be taught analytical capacity to generate changes in their attitudes and behaviours. Such a plan implies that if parents continue to support their children's participation in work, it is because they lack reflective or analytical capacity.

\section{FRAMING CHILD LABOUR AS 'CULTURAL'}

Efforts to reform parents' behaviour were central to internationally-funded programs and projects focusing on children's rights - especially the right to be free from economic exploitation and the agreement to implement minimum age laws at which young people could engage in paid labour (reflected in Article 32 of the CRC). While stated policies and laws focused on both fathers and mothers, in practice most NGOs and governments targeted mothers exclusively. ${ }^{6}$ In line with Foucault's (1991) studies of governmentality, I suggest that children's work in public spaces is framed as a problem to be addressed through social service and NGO's provisions and education. However, rather than target children themselves, many programmes target mothers, creating educational programs that teach self-discipline and the 'dangers' of child labour. The 'problem' of children's work can then be interpreted as a problem of poor governance of the family, rather than inequalities produced by structural adjustments, a lack of well-paid work opportunities, or historical exclusion, as mentioned above. Martinez Novo (2003) argues that practices that result from poverty, such as street vending or child labour, are problematically attributed to 'culture'. Indigenous women are then framed as 'bad mothers who exploit their own children' when children accompany their mothers to work as informal street vendors (Martinez Novo, 2003: 259).

Governance strategies increasingly frame mothers as clients with responsibilities to themselves and their families, and in doing so, place the onus for development squarely on their shoulders (Miller and Rose, 1990, as cited in Rankin, 2001: 29). Ironically, some dominant interpretations of children's rights facilitate this discursive shift of responsibility from the state to the family through their emphasis on narrow understandings of what childhood should look like. Representations of needy children, abandoned by their parents (Ruddick, 2003), are contrasted with supposedly universal images of childhood to justify increased regulation of both children and their parents. Such interpretations reinforce neoliberal understandings of poverty as the result of individual characteristics and allow elites in power to focus on helping parents reform their own behaviours (Nieuwenhuys, 2008), rather than adapting more relational approaches that look at the societal and economic relationships producing poverty. Yet, because children's discourses have a veneer of moral respectability around them, they are not subject to as much scrutiny.

In an article in La Republica, one of Peru's primary newspapers, the director of children's programs for Telefonica explained that poverty "is not the principal cause of child labour...there is a cultural component. The majority of parents of children who work also worked when they were children but what they don't see is that they are still trapped in poverty because when they had to study they did not (La Republica, 2013, emphasis mine). An emphasis on parents not 'seeing' shifts the focus of poverty reduction to educating parents; child labour and the importance of formal schooling (or lack thereof) are then reframed as values that parents do not appreciate. Such a framework suggests that if parents can learn new values, they will be able to break the cycle of intergenerational poverty.

At the end of the summer play put on by an NGO working to end child labour, the director opened the event with a speech about the importance of withdrawing children from work, and allowing them the space to play and to experience a 'real childhood.' The children then acted out a play in which a lazy mother sends her children to the streets to work so she can go to the beauty parlour for the whole day. She gruffly tells the children, "If you want to eat, you need to work." The message of the play was clear. The mother was lazy, exploiting the children so that she did not have to work. By the end of the play, the mother realises the dangers of her selfish behaviour, and changes, agreeing to work so that her children will not have to. However, the majority of working children I

\footnotetext{
${ }^{6}$ In one interview, one social worker said that there was no point in trying to reach fathers because they would not attend events. Another said that fathers drink, or have other families, and rarely educate their children as they should.
} 
met had mothers who worked even longer hours than they did. By presenting such a play, economic need and the difficult decisions mothers face daily were trivialised.

Without a more comprehensive outlook, simply campaigning against child labour not only does not offer a practical solution but might have negative psychological effects. Ten-year old Sonya, who lived in a poor neighbourhood in the hills of Lima, had to constantly listen to the message that her childhood was not 'real' and that she should not be working. Unsurprisingly, Sonya and many other children were defensive when I would ask questions about their mothers. They would reiterate that they themselves chose to work; no one forced them to work. "My mother is not bad", Sonya insisted. "I don't like it when people talk. They don't know" (interview, 2010). Such comments indicate children's awareness of discourses promoting ideas related to maternal blame, and programs' increased efforts to regulate and reform the behaviours of poor mothers.

The paternalistic attitudes with which parents are treated extend beyond formal events. One day, I was walking with one of the educators from an NGO that also aimed to eradicate child labour. We ran into a mother of two of the girls who participated. The educator stopped her, explaining that she was worried about the 11 -year old daughter's behaviour:

Educator: Your daughter is withdrawn. She doesn't play like the other children. Maybe something happened. Maybe something happened at the dump [the daughter goes early in the mornings to look for items to recycle]. She should not be working there. It is an ugly place, filled with ex-convicts and other dangerous men.

Mother (mumbling): I don't send her to work. She just goes.

Educator: You say you don't send her but then you accept the money. You need to assert your authority as a mother. My two children stay home when I am gone because I tell them to. I don't have to lock the door.

Mother (nodded): Yes.

Educator: Your daughter has a right to be a child and to play. She will learn from you. You don't want her to stop coming home to sleep at age 15. As mothers, we want our kids to have better lives than us.

(Aufseeser, Field notes, 2010)

The educator spoke in an instructive manner, telling the mother how mothers should feel and act. She pointed out inadequacies in the mother's parenting by comparing the mother to herself, who by implication, was a much better mother. She suggested that the daughter's work at the dump, along with her more withdrawn behaviour, were a sign of poor mothering, interpreted mostly as the result of ignorance. The educator made it clear that the mother was setting a poor example but appealed to the notion that because she was a mother, she would want her child to have a better life and would reform her behaviour. Impediments to, and different understandings of, motherhood, along with the actual context of the mother's life, were mostly ignored. After the mother had left, the educator explained to me that the younger daughter would wander throughout the neighbourhood. She clearly saw this as a sign that the mother was not appropriately caring for her. Although there was some recognition of difficult circumstances in her life (the mother's husband was physically abusive, and did not support the family much financially), the emphasis was on reforming the mother's behaviour so that it more clearly meshed with dominant understandings of motherhood. Additionally, the conversation reflected assumptions that child labour, compared to domestic violence or any number of reasons, was responsible for the change in the daughter's behaviour. The significance of disciplining mothers through children's rights is that it hides the unequal power relations that are more evident in other forms of coercion. If mothers are to speak out, they risk being branded as 'uncaring' or 'bad mothers'.

In another NGO, for the children to receive homework help or participate in sports and arts classes, their mothers must also attend bi-weekly meetings, for which they receive points. At the sessions, in addition to learning about cooking nutritious meals and proper parenting, mothers are encouraged to develop proposals for microbusinesses. The mother that earns the most points at the end of the program receives $\$ 200$ to start her own business. While this clearly may be beneficial for one family, it does nothing to address a general lack of job opportunities, low wages, or other conditions which contribute to the near-universal poverty of the group more generally. Even more importantly, it reproduces understandings that with hard work, one can pull herself up. And through competition and rankings (reflected in the point system), it reinforces individual responses to poverty. Such values resonate with other studies documenting the way in which social services work to create entrepreneurial self-sufficient subjects (Kingfisher, 2002; Marquardt and Schreiber, 2015). They also re-enforce 
attitudes that poverty is a matter of personal work ethic, rationality and individual skills, rather than the systemic processes of marginalisation.

Even in situations where educators and social workers expressed understanding of the complex factors shaping child poverty, they nonetheless focused on the mothers, or the families more generally, as primary obstacles to fulfilling children's rights. A social worker who coordinated an after-school support program for working children explained that the main limitation to the program's effectiveness was "resistance from the parents. Some families are accustomed to receiving assistance, three meals in the dining halls. It is difficult to say, 'leave this. Change.' They don't change" (interview, 2010). Even organisations that take a very different political approach to children's work, such as a Peru's Movement for Child and Adolescent Workers, shared the mentality that unless mothers are educated, their actions can be detrimental to their children's well-being. "Many mothers do not care. They do not want to attend events. But they want their children to have access to the dining hall and the activities. Little by little, we teach them the importance of participation and rights" (interview, 2011, emphasis mine). By refusing to submit to particular forms of governance, mothers are depicted as 'uncaring.' The educator did not reflect on the complex factors that shape how mothers, children and other family members spend their time. Instead, she, like other program staff, return to the trope of the 'bad' mother who fails to fulfil her natural duty to put her children first--with what putting children first means defined narrowly.

\section{'OUT OF PLACE' IN THE STREETS}

The regulation of poor mothers also reflects longstanding tendencies that link indigeneity with backwardness, and position indigenous women as bad mothers for exploiting their children by sending them to work in the street (see Aufseeser, 2014; Swanson, 2007). More established and wealthy Peruvians often made assumptions about women living in informal communities, depicting them as dirty and promiscuous, "unnatural mothers who do not hesitate to throw their young children to the streets to beg or work, instead of sending them to school and feeding them a balanced diet" (Barrig, 1982, 15, as cited in Alcalde, 2010: 50). Social workers and educators reflect such attitudes in the assumptions they make about indigenous women, and beliefs that they are culturally ignorant.

Elsewhere, I have argued how Peru's Bill to Protect Children from Forced Begging ultimately provided a tool through which the government could regulate poor children and their parents (Aufseeser, 2014). Although Peru's law against begging is now well over a decade old, little has changed in the language used to describe mothers 'exploiting' children on the streets of Lima. In El Comercio, a leading newspaper in Peru, Rosas (2018) writes about a group of four women who sit while their children run around begging for diapers, food, clothing and money. The article emphasises that the women 'utilize the little ones to earn more'. However, it provides no specific details about the women or children and their situations. The article quotes a representative of UNICEF-Peru, "With these activities, the children's rights are violated." Yet, the presence of children in public spaces in and of itself is not necessarily indicative of exploitation. The trade-off between leaving children home and bringing children to work involves negotiating risks in either situation. Thus, mothers are expected to be both breadwinners and primary caregivers but are limited in their attempts to do so.

Many assume that indigenous women have their children with them to gain more sympathy. In Cusco, foreign tourists commented that mothers tried to manipulate their emotions and use their children for financial gain. "It is hard to say no to a child patting her stomach," a French woman volunteering at a children's home said. "But the longer I stay here, the more I learn that these children have mothers, who just sit around while the kids work" (interview, 2011). Yet, mothers are rarely 'just' sitting around, but also may be watching their children work and play, making crafts for the children to sell, or are themselves also selling, as was the case with Anita. Anita had moved from a rural part of the state of Cusco to the city of Cusco shortly after her first child was born. Her husband was an alcoholic and stayed behind in their village. After Anita's daughters finished school, she would often accompany them to Cusco's main plaza. While the girls walked around, selling artisan goods to tourists, Anita would sit with another mother, weaving bracelets for her daughters to sell, caring for her youngest son, and actively watching to make sure her daughters were safe. She explained, "The girls sell a lot more. The [municipal police] take supplies from older women when we try to sell but they do not bother children... we don't come if they have school assignments or assemblies. If we haven't earned enough money, at night, I will come back out and work. I don't want the girls here at night" (interview, 2010). Anita's comments challenge simplified claims that mothers of working children are ignorant or lazy and instead indicate that decisions about who works, when and where, are part of complex family strategies, and involve frequent trade-offs.

Perceptions that mothers deceptively utilise children for financial gains extend beyond analyses of children's interactions with tourists. Police officers at the Family Commission in Cusco expressed nuanced, and sometimes contradictory views. One officer explained that most children picked up by the police were in the streets because of economic need rather than intentional exploitation. His partner, on the other hand, attributed children's presence in the streets to 'culture'. Yet, both discussed how children were not actually from the city of Cusco, but 
rather elsewhere. They echoed discourses depicting indigenous children and families as 'out of place' in the city (Aufseeser, 2014). While these attitudes are not new, the prevalence of international organisations supporting anti child-labour campaigns in the name of children's rights provide moral and financial support to such views, and the means to reframe inequality as 'a cultural issue' (see Martinez Novo, 2003, for a critique of a link between 'ethnic practice' and street work in Mexico).

The majority of mothers with whom I spoke specifically emphasised that they did not want their children to work in the streets, and were aware of various risks that their children negotiated in the context of their everyday lives and work. Thus, project efforts that focus on teaching mothers about the danger of street work or reforming their behaviour are misguided, and fail to reflect the reality of the tradeoffs that mothers constantly negotiate.

\section{COMPLEX TRADEOFFS: EXPLORING THE IDENTITY OF THE 'GOOD MOTHER'}

Mothers negotiate competing discourses of what it means to be a good mother with efforts to meet their own, their children's, and other family members' needs. They are bombarded with images and messages that naturalise their role as their children's protectors. For example, in an interview in Peruvian newspaper Redaccion Trome, psychologist Vanessa Herrera explained that 'delinquents come from families without values':

Interviewer: What should a mother do if someone assaults her child?

Herrera: The mother is the pillar for her child, her role is protector. She cannot permit for any motive that anyone hit her child, even if they [the child] have done something very bad. Otherwise, the youth will grow feeling alone and abandoned.

Interviewer: There are mothers who support their partners when they hit their children.

Herrera: It is certain, in many families, mothers-and also fathers-are complicit with aggression. (...) the woman must be a mother before being a woman. (Parades, 2015).

In her role as an 'expert,' Herrera's comments reflected beliefs that women must put their identity as mothers before other identities and make whatever sacrifices are necessary to protect their children; if children are hurt, mothers share at least part of the blame for failing in their maternal role as protectors.

Many of the mothers with whom I spoke also reinforced ideals of 'sacrifice' and 'protection' as key components of motherhood. Thirty-six year-old Teresa had slept on the streets since she was seven years old. Both of her children were born due to sexual abuse. She explained, "I was afraid I would reject him [her first son] but when I saw him so defenseless, I had to protect him. I thought, 'God has sent him to save me.' To be a mother is to make sacrifices without hoping for anything. They [her parents] were not like that with me but I did not want to repeat history. I have made mistakes but when [my son] kisses me on the forehead and says, 'I love you, mama', it is the best reward." Her comments further reflect a common argument that mothers do not need any economic or material support for their social reproduction work because love or care should be reward enough.

Isabela, a 32-year old who had migrated from the highlands as a child, was living in a small rented room with her three children in downtown Lima. She reiterated the belief that being a mother is a blessing. She had spent much of her childhood in the streets and had a lot of anger towards her mother. "Some children work because their fathers leave, they drink, they start a new family (....) I was abandoned by a woman," she emphasised, "who did not know how to value the blessing of being a mother." Isabela held mothers to higher standards in terms of commitment to their children than she did fathers.

Even mothers whose actions arguably went against 'global' ideas of childhood frequently justified their actions by appealing to notions of good motherhood. I met 28 -year old Fiorella, originally from Cajamarca, a region in the highlands, on the corner of a busy intersection in a lower-income neighborhood in Lima. Her son Paul sold candies to drivers stopped at lights. Fiorella said, "We need to pay for Paul's school fees, for food. His father left us. What am I supposed to do? There is no one to help me. What choice do I have? I must work all day to provide for my children." On multiple occasions, Fiorella would ask me for resources for her children, ranging from clothing and sneakers to money to buy food. Other mothers would make comments that Fiorella was 'always trying to get something.' However, Fiorella was actively working to provide for her children in any way she could. Rather than seeing her as enterprising, other mothers framed her as manipulative, and would try to differentiate themselves from her. "Fiorella is more focused on her new partner. She does not take care of her children. Paul skips school and goes to use the internet. She is teaching him to expect handouts" Andrea explained (field notes, 2011). Approaches that focus on the individual worth of mother's actions actively work to reinforce attitudes of poverty based on character and culture. 
Mothers often find themselves in 'Catch-22' situations. On the one hand, in seeking social support for their children, women can reaffirm a vision of themselves as 'good mothers'. Yet, they must negotiate a subtle line: mothers need to be enterprising but not exploitative. Especially in the situation of indigenous women, some wealthier Peruvians and international NGO workers suggested that women used their children to seek more financial assistance. For example, a social worker for families in a village a few hours outside of the city of Cusco explained, "Some women have children just to make sure they are still eligible for benefits" (interview, 2010).

The idea of parental irresponsibility in the form of having too many children emerged in conversations throughout my time in Peru. Jose, a municipal police officer in Lima, explained that child poverty continued to exist because "parents don't plan well. They don't think about their limited capacities and instead breed like cuy (guinea pigs). They don't think about whether their money will be sufficient if they keep having kids... The serrenos [highlanders] come to Lima and think life will be easy but then they can't take care of all the kids" (interview, 2010). His comments, which are linked to stereotypes of Peruvian highlanders, are revealing in their tendency to blame poverty on the actions of 'overbreeding' parents, who do not think through their actions. Such comments fail to consider actual resource use, they also naturalise the current distribution of resources, implying that poor parents should work within the constraints of their personal economies when deciding to have children, rather than questioning the way goods are distributed in the first place. Such beliefs are influenced by growing interest of international organisations with population control (Rojas, 2004; Mitchell, 1995). Further, they overlook the government's history of regulating poor women's fertility, through programs such as Fujimori's Family Planning Program, which relied on the forced sterilisation of women in poor areas. While forced sterilisation no longer occurs, some women continue to avoid reproductive health service because of discrimination, disrespect and misunderstanding (Boesten, 2010). Further, poor women, especially adolescents, have more limited access to contraceptives than do their wealthier counterparts, and must often negotiate stigma and bureaucracy when trying to access available services. Yet, such factors and inequalities are overlooked in the tendency to blame women for having too many children and hence perpetuating their own poverty.

Beyond efforts to 'scam' Juntos, indigenous mothers are depicted as 'working the system.' Throughout the month of December, local politicians host chocolotadas, Christmas events in which they give toys and hot chocolate to children in the area while also attempting to gain electoral votes from Perús poorer population. Yet, many government staff, along with wealthier mestizo populations, expressed concern about the number of indigenous mothers who would travel hours around the city to receive multiple gifts and snacks from various municipalities, despite little indication that such behaviours occurred on any wide scale. In categorising mothers' behaviour as immoral, they overlook how such behaviour may be a sign of pro-active parenting, as parents work to get more material items for their children. Such comments also fail to consider the complex and exploitative relationship of regional governments with indigenous populations.

On subsequent visits to Peru, some of the youth with whom I worked initially had themselves become mothers. In some cases, this shift in identity did not result in any immediately discernible changes in either youth behaviours, or the ways in which they were treated. But in others, becoming a mother, and the subjectivities that young people linked with good motherhood, did prompt a change. The ways in which this change manifested were contradictory. For example, in the case of 25 year old Ana, she stopped selling drugs because "Jose [her son's] father is in jail, and the police are doing more round-ups. If I sell drugs, I might get arrested and then Jose would have no one. Now I sell food during the day, and I bring Jose with me" (interview, 2011). In some situations, Ana would stay with the food cart, and Jose would walk up and down busy intersections, selling snacks to drivers waiting for the light to change. In theory, Jose could be picked up by police for his work in the streets. Yet, it is not actually clear what choices will lead to the best outcomes for children or their mothers. In Andean society, mitigating risks associated with poverty is a collective rather than individual responsibility (Crivello and Boyden, 2011). ${ }^{7}$ In smaller villages, extended communities collectively keep an eye on young people. However, as newcomers to urban areas, some families do not have the same networks - they are faced with the choice of leaving children alone when they go to work, or of bringing their children with them. Further, snap judgments that equate streets with risk ironically may increase that very risk by minimising the importance of analysing actual conditions of exploitation. By this I mean that if the any child in the streets is automatically assumed to face exploitation, there is no need to further distinguish between the different situations in which children work. Mothers are then disenfranchised from making the best decisions for their children, and instead need to negotiate image and representation, while also mothering in a context of poverty, the neoliberalisation of responsibility, and active discrimination.

I met Cecilia when she was enrolled in a primary school for working children. At the time of my last visit, Cecilia had recently turned 18 and given birth to her second child. "For me, being a good mother involves protecting a child and teaching him by demonstrating examples. I often think that I should not have become a mother so young. But I am also blessed to have two beautiful children. And I will use whatever forces I can to

\footnotetext{
${ }^{7}$ In this sense, individual roles and expectations are strongly shaped by collective aspirations-yet, such an outlook contradicts Western conceptions of individual rights.
} 
give them what I could not have during my own childhood... I worked since I was six. I needed to sell with my brothers to buy clothes or toys... sometimes we were dying of hunger, my mom the most. She would give us what little she had." Cecilia expressed not wanting to repeat certain aspects of her own childhood. At the same time, in her reflections, she frequently emphasised the sacrifices her mother had made to give them what she could. Throughout the time I knew her, Cecelia negotiated complex feelings of shame, pride and anger at her mother and Cecilia's own role as a working child. The teacher at the school Cecilia attended repeatedly explained that Cecilia's mother did not value schooling and did not know how to 'educate' her own children. "She [Cecilia's mother] cannot control her own children. She prefers that they work instead of study. That is why Cecilia got pregnant. This is why [the family] will continue to live in poverty" (interview, 2014). Her comments echoed common views that parents caused their children's poverty, expressed by a wide range of people, including government officials, elite Peruvians, and economically disadvantaged children themselves. Yet, in longitudinal research with Peruvians in Lima, Anderson (2007) found that a lack of opportunity and structural inequalities perpetuated intergenerational poverty much more than did parents' value.

Cecilia made the decision to leave her children with her mother or a neighbour when she went to sell. She did not want them to feel the same shame she had felt walking for hours in the streets of Lima's wealthier neighbourhoods. In other situations, women reported working to create care networks for their children. Thirtytwo year old Sumaq was born in a small village outside of Cusco, where she explained, "I always brought [my daughter] to the fields with me. And we all helped each other. Here, in the market, I can watch her. When I am selling, she goes to Ursula's [one stand over]. Pedro [Ana's older brother] comes when he gets out of school and helps her with her homework. She sometimes watches the stand for me when I have to go to buy things or go back to the house to cook." Their comments also reflect ways in which children's well-being is integrated into family well-being.

Neoliberal forms of governance emphasis the individual over the collective (Gallagher, 2012). However, in doing so, they fail to recognise the interconnectedness of different family members' subjectivities. Viewing needs independently overlooks the ways in which children and mother's needs are different but also intertwined. Allowing children to work as selling artisan goods may be a practical livelihood strategy. In Cusco's main plaza, children are often more successful at vending than are their mothers-primarily because the municipal police confiscate supplies from adult vendors to prevent them from entering the plaza but are much more likely to allow children to sell artisan goods to tourists, as was the case with Anita's family. Yet, analyses of global childhood emphasise the negatives of labour, rather than recognising that all decisions involve complex tradeoffs (Aufseeser et al, 2018). Working in the plaza provides girls with a place to run around and play with friends, while under the supervision of their mothers, who sit nearby. While in most situations, the girls give the money they earn to their mothers, the money is used to purchase food for the family, pay the children's school fees and for other needed resources in the house. In Peru, although public schools are supposedly free, families must pay for school supplies, Parent Teacher Association fees, and school uniforms, which can cost up to the equivalent of $\$ 100$. By allowing children to vend, mothers supervise their children while also facilitating greater economic income for their families. Theorising women and children's needs as either entirely separate, or intertwined as 'womanandchildren' overlooks intersubjectivity, and the way decisions are made within families (Punch, 2002).

Further, although campaigns against child labour are carried out in the name of children's well-being, multiple children in this study discussed how badly they felt when NGO staff criticised their mothers. In early conversations with twelve-year old Kimi, who lives in an informal community on the outskirts of Lima, she explained that her mother worked in a factory most of the day, so Kimi would help her aunt sew clothing after school to avoid being in an empty house. However, as we spoke more, Kimi explained that her mom was sick and unable to work, and the 'aunt' that she helped was a woman in the neighbourhood. "People don't understand. My mom wants me to study. She wants me to have a better future. She didn't finish school. But we also need money. My mom is a good mom" (interview, 2014). Young people are aware that their mothers are frequently viewed as the main agents of their exploitation. However, even in situations in which a parent does send a child to work, teaching the value of labour through practice may provide a more practical effort to prepare their children for the future than does keeping them alone in an empty home (also see Campoamor, 2016).

\section{CONCLUSION}

In this article, I have shown ways in which children's rights discourses have been used to discipline and blame poor mothers for their children's poverty. In doing so, they obscure structural factors contributing to child poverty and instead reframe poverty as cultural. Mothers are assumed to lack the self-discipline and knowledge to act in the best interest of their children. Especially as it pertains to children's work, rights advocates and development practitioners alike make assumptions that children in the streets are at worst being forced to work by exploitative mothers, and at best, are working because their mothers do not understand the risks their children face in the 
streets. Yet, because of the assumed progressive nature of children's rights, policies carried out in the name of children's well-being have not been subject to as much scrutiny as have other conditional welfare programs. Appeals to global childhoods are then translated into notions of 'global motherhood', defined on the basis that mothers should actively work to facilitate childhoods spent in school, with the family, and in play. If mothers fail to do so, they are branded as 'uncaring'.

The mothers in this study both challenge and reinforce these representations of 'global motherhood'. While actions such as permitting children to work in public space are framed as problematic, in many situations, mothers understand their children's work as part of an active strategy to supervise their children or facilitate more opportunities for them. Powerful discourses of what children should be doing and where hinder acknowledgment of the competing tensions that mothers must negotiate. Instead children's rights discourses provide a tool that policy makers, NGO staff, and educators use to focus attention on 'problematic' behaviours of mothers. Further, as demonstrated by comments from some of the mothers, they not only resist but also internalise representations of 'global motherhood', justifying their behaviours through appeals to sacrifice, child well-being, and some of the very same notions that shape ideas of 'global motherhood'. In this way, children's rights legislation and discourses provide a powerful logic not only shaping the ways in which poor mothers are disciplined, but also shaping mothers' own subjectivities and ideas about what motherhood means.

In practice, children's rights are often framed within a neoliberal framework, as something possessed by an individual, with an emphasis on the ability to become an entrepreneurial subject (see Nieuwenhuys, 2008). This not only shapes particular understandings of what childhood looks like, but also relegates the role of the mother to the background, as someone who fulfils, or in this case, hinders the fulfilment of individual children's rights. Yet, a neoliberal rights' based framework fails to reflect the intersubjectivity of rights. In the case of motherhood, the very identity of a mother can only come into existence in relation to others. Recognising this interdependency highlights limitations in trying to separate women's rights from children's rights, or subsume one under the other. Just as children's rights can only be exercised in the context of specific relationships, motherhood is also a socially constructed embodied experience. Such recognition calls into question the ability to invoke children's rights to discipline or punish poor mothers and instead necessitates a relational analysis of family well-being.

\section{REFERENCES}

Aitken, S., Lund, R. and Kjorholt, A. (2008). Global childhoods: Globalization, development and young people. London: Routledge.

Alcalde, M. (2010). The woman in the violence: Gender, poverty and resistance in Peru. Vanderbilt University Press.

Anderson, J. (2007). Urban poverty reborn: A gender and generational analysis. Journal of Developing Societies, 23(12), 221-241. https://doi.org/10.1177/0169796X0602300213

Aufseeser, D. (2014). Control, protection and rights: a critical review of Peru's begging bill. International Journal of Children's Rights, 22, 241-267. https:// doi.org/10.1163/15718182-02202001

Aufseeser, D., Bourdillon, M. Carothers, R. and LeCoufle, O. (2018). Children's work and children's well-being: Implications for policy. Development Policy Review, 36(2), 241-261. https://doi.org/10.1111/dpr.12215

Boesten, J. (2010) Intersecting inequalities: Women and social policy in Peru, 1990-2000. University Park, PA: Pennsylvania State University Press.

Bolin, I. (2006). Growing up in a culture of respect: Childrearing in higbland Peru. Austin: University of Texas Press. https:// doi.org/10.1525/ilca.2006.11.2.430

Bourdillon, M. (2006). Children and work: A review of current literature and debates. Development and Change, 37(6), 1201-1226. https://doi.org/10.1111/j.1467-7660.2006.00519.x

Bradshaw, S. and Viquez, A. (2008). Women beneficiaries or women bearing the cost? A gendered analysis of the Red de Proteccion Social in Nicaragua. Development and Change, 39(5), 823-844. https://doi.org/10.1111/j.14677660.2008.00507.x

Burman, E. (2008). Beyond 'women vs. children' or 'womenandchildren': Engendered childhood and reformulating motherhood. The International Journal of Cbildren's Rights, 16(2), 177-194. https://doi.org/10.1163/157181808X301773

Campoamor, L. (2016). 'Who are you calling exploitative?' Defensive motherhood, child labor and urban poverty in Lima, Peru. The Joumal of Latin American and Caribbean Anthropology, 21(1), 151-172. https://doi.org/10.1111/jlca.12169

Cassiman, S. (2008). Resisting the neo-liberal poverty discourse: On constructing deadbeat dads and welfare queens. Sociology Compass, 2(5), 1690-1700. https://doi.org/10.1111/j.1751-9020.2008.00159.x

Crivello, G. and Boyden, J. (2011). Situating risk in young people's social and moral relationships. Oxford: Young Lives.

Cussianovich, A. (2006). Ensayos sobre infancia: Subjeto de derechos y protagonista. Lima: IFEJANT. 
Departamento de investigacion y documentacion parlamentaria. (2018). Importancia estadistica de la poblacion Peruana Quechua, Aymara y Nativa de la Amazonia, y legislacion sobre escanos reservados para pueblos originarios en America Latina. Lima: DIDP.

Enloe, C. (1990). 'Womenandchildren': making feminist sense of the Persian Gulf Crisis. The Village Voice, 25(9).

Ewig, C. (2006). Global processes, local consequences: gender equity and health sector reform in Peru, Social Policy 13, 427-455. https://doi.org/10.1093/sp/jx1002

Foucault, M. (1991). The Foucault effect: Studies in governmentality. Chicago: University of Chicago Press.

Gallagher, A. (2012). Neoliberal governmentality and the respatialisation of childcare in Ireland. Geoforum, 43(3), 464-471. https://doi.org/10.1016/j.geoforum.2011.10.004

Hays-Mitchell, M. (2002). Resisting austerity: a gendered perspective on neo-liberal restructuring in Peru, Gender and Development, 10, 71-81. https:/ / doi.org/10.1080/13552070215920

Invernizzi, A. and Williams, J., eds. (2008). Children and citizenship. London: Sage.

Kingfisher, C. (2002). Neoliberalism 1: Discourses of personhood and welfare reform. Western welfare in decline: Globalization and women's poverty, 13-31. Philadelphia: University of Pennsylvania Press. https:// doi.org/10.9783/9780812202472.13

Kingfisher, C. and Maskovsky, J. (2008). Introduction: the limits of neoliberalism, Critique of Anthropology, 28(2), 115-126. https://doi.org/10.1177/0308275X08090544

Leibel, M. (2006). Malabaristas del siglo XXI. Lima, Peru: IFEJANT.

Leinaweaver, J. (2006). Los Ninos Ayacuchanos. Lima: IEP.

Leon, J. (2013). Addressing transitory and chronic poverty: Social policies in Peru 1990-2010. Social Protection, Growth and Employment, 99.

Marquardt, N. and Schreiber, V. (2015). Mothering urban space, governing migrant women: the construction of intersectional positions in area-based interventions in Berlin. Urban Geography, 36(1), 44-63. https://doi.org/10.1080/02723638.2014.961358

Martinez Novo, C. (2003). The 'culture of exclusion: Representations of indigenous women street vendors in Tijuana, Mexico. Bulletin of Latin American Research, 22(3), 249-268. https:/ / doi.org/10.1111/1470-9856.00077

Ministerio de la Mujer y Desarrollo Social (MIMDES) (2012). Plan Nacional de Accion por la Infancia y la Adolescencia, 2012-2021. Lima, Peru: MIMDES.

Molyneux, M. (2006). Mothers at the service of the new poverty agenda: Progresa/oportunidades, Mexico's conditional transfer programme. Social Policy and Administration, 40(4), 425-449. https://doi.org/10.1111/j.14679515.2006.00497.x

Monk, J. and Hanson, S. (1982). On not excluding half of the human in human geography. The Professional Geographer, 34(1), 11-23. https:/ / doi.org/10.1111/j.0033-0124.1982.00011.x

Nieuwenhuys, O. (2001). By the sweat of their brow? Street children, NGOs and children's rights in Addis Ababa. Africa, 71(4), 539-557. https://doi.org/10.3366/afr.2001.71.4.539

Nieuwenhuys, O. (2008). Embedding the global womb: global child labour and the new policy agenda, in S. Aitken, R. Lund and A. Kjorholt (eds), Global Childhoods: globalization, development and young people. (pp.149-164). London: Routledge. https://doi.org/10.1080/14733280601108312

Paredes, T. (1 Feb 2015). Psiquiatra Vanessa Herrera: 'Los delincuentes vienen de familias sin valores.' Redaccion Trome. Available at: http://archivo.trome.pe/actualidad/psiquiatra-vanessa-herrera-delincuentes-vienenfamilias-sin-valores-2038027

Punch, S. (2002). Youth transitions and interdependent adult-child relations in rural Bolivia. Journal of Rural Studies, 18(2), 123-133. https:// doi.org/10.1016/S0743-0167(01)00034-1

Pupavac, V. (2002) The international children's rights regime, in D. Chandler (ed.), Retbinking buman rights (pp. 5775). London: Palgrave Macmillan. https://doi.org/10.1057/9781403914262_4

Rankin, K. (2001). Governing development: neoliberalism, microcredit, and rational economic woman. Economy and Society, 30(1), 18-37. https://doi.org/10.1080/03085140020019070

Republica (June 5 2013). La pobreza no es factor fundamental en el trabajo infantil. La Republica. Available at: https://rpp.pe/lima/actualidad/la-pobreza-no-es-factor-fundamental-del-trabajo-infantil-noticia-601561

Roberts, D. (1991). Punishing drug addicts who have babies: Women of color, equality and the right of privacy. Harvard Law Review, 1419-1482. https:/ / doi.org/10.2307/1341597

Rosas, Y. (19 Aug 2018). Dia del Nino: explotacion infantile sigue existiendo en las calles de Lima. El Comercio. Available at: https://elcomercio.pe/lima/sucesos/dia-nino-explotacion-infantil-continua-calles-lima-noticia548331

Rosen, R. and Twamley, K. (2018) Feminism and the politics of childhood: Friends or Foes? London: UCL Press. https://doi.org/10.2307/j.ctt21c4t9k

Ruddick, S. (2003). The politics of aging: globalization and the restructuring of youth and childhood, Antipode, 35 , 345-362. https://doi.org/10.1111/1467-8330.00326 
Ruddick, S. (2007). At the horizons of the subject: neo-liberalism, neo-conservatism and the rights of the child part one: From 'knowing' fetus to 'confused' child. Gender, Place and Culture, 14(5), 513-527. https://doi.org/10.1080/09663690701562180

Schroeder, K. (2006). A feminist examination of community kitchens in Peru and Bolivia. Gender, Place and Culture, 13(6), 663-668. https://doi.org/10.1080/09663690601019844

Seligmann, L. (2012). Contested spaces: street vendors in the Andean metropole of Cusco, Peru, in I. Pardo and G. Prato (eds) Anthropology in the city: Methodology and theory (pp. 117-134). New York: Routledge. https://doi.org/10.4324/9781315567310-6

Swanson, K. (2007). 'Bad mothers' and 'delinquent children': unravelling anti-begging rhetoric in the Ecuadorian Andes. Gender, Place and Culture, 14(6), 703-720. https://doi.org/10.1080/09663690701659150

Thorp, R. and Paredes, M. (2010). Ethnicity and the persistence of inequality: The case of Peru. New York: Palgrave Macmillan. https://doi.org/10.1057/9780230293137

Van Dijk, T. (2001). Critical discourse analysis, in D. Schiffrin, D. Tannen, and H. Hamilton (eds) The handbook of discourse analysis (pp. 352-371). Massachusetts: Blackwell Publishers.

Yamada, G. (2005). Horas de trabajo: determinantes y dinamica en el Peru urbano. Lima: Universidad del Pacifico.

Citation: Aufseeser, D. (2019). Mothering in the Context of Poverty: Disciplining Peruvian Mothers through Children's Rights. Feminist Encounters: A Journal of Critical Studies in Culture and Politics, 3(1-2), 13. https://doi.org/10.20897/femenc/5919

Copyright (C) 2019 by Author/s and Licensed by Lectito BV, Netherlands. This is an open access article distributed under the Creative Commons Attribution License which permits unrestricted use, distribution, and reproduction in any medium, provided the original work is properly cited. 